\title{
Penerapan Metode EPQ(Economic Production Quantity) Pada Pengendalian Bahan Baku Laundry Di Samarinda Laundry Mart Barbasis Android
}

\author{
Hanifah Ekawati ${ }^{1}$, Pitrasacha Adytia ${ }^{2}$, Yunita $^{3}$ \\ STMIK Widya Cipta Dharma ${ }^{1,2,3}$ \\ Jl. M. Yamin No.25, Samarinda \\ Sur-el : hanifah@wicida.ac.id ${ }^{1}$, pitra@wicida.ac.id², yunibas80@gmail.com³
}

\begin{abstract}
Samarinda Laundry Mart is a business that provides laundry services, besides that it is also a supplier of laundry raw materials in Samarinda. Control of laundry raw materials in the laundry business is a complicated problem. Therefore one method that can be used for raw material control is the EPQ method (Economic Production Quantity) where the EPQ method can determine the optimal production level, optimal production frequency, optimal time cycle to minimize total inventory costs. The results of this study are made inventory control applications using the EPQ method that can make calculations automatically. Only by entering monthly data that is already available. Users can also make transactions using the application so that all data has been integrated in the database to facilitate management in the laundry business. In addition, this application can also print transaction reports and turnover reports.
\end{abstract}

Keywords: EPQ method, inventory control, inventory, raw materials.

\begin{abstract}
Abstrak: Samarinda Laundry Mart merupakan sebuah usaha yang menyediakan jasa binatu, selain itu juga sebagai salah satu produsen bahan baku binatu didaerah Samarinda. Pengendalian bahan baku binatu didalam suatu usaha binatu adalah suatu hal yang rumit. Oleh karena itu salah satu metode yang dapat digunakan untuk pengendalian bahan baku adalah metode EPQ (Economic Production Quantity) dimana metode EPQ dapat menentukan tingkat produksi optimal, frekuensi produksi optimal, siklus waktu yang optimal untuk meminimumkan biaya persediaan. Hasil dari penelitian ini adalah dibuatnya aplikasi pengendalian persediaan menggunakan metode EPQ yang dapat membuat perhitungan secara otomatis. Hanya dengan memasukkan data bulanan yang sudah tersedia. Pengguna juga dapat melakukan transaksi menggunakan aplikasi sehingga semua data sudah terintegrasi didalam database untuk memudahkan manajemen pada usaha binatu. Selain itu aplikasi ini juga menyediakan laporan transaksi dan laporan omset.
\end{abstract}

Kata kunci: metode EPQ, pengendalian persediaan, persediaan, bahan baku

\section{PENDAHULUAN}

Laundry merupakan sebuah usaha yang menyediakan jasa pencucian pakaian, karpet, dan alat-alat rumah tangga lainnya. Dalam sebuah usaha laundry butuh strategi yang baik untuk bisa bersaing dengan setiap laundry. Dengan didukung pengendalian bahan baku yang baik akan mempermudah laundry dalam memanajemen persediaan bahan baku [1-3].
Samarinda Laundry Mart merupakan sebuah usaha laundry yang berada di Samarinda, Kalimantan Timur merupakan usaha laundry yang cukup besar. Agar dapat memenuhi permintaan pelanggan laundry yang tinggi maka kegiatan layanan laundry harus dilakukan secara optimal. Salah satu hal yang harus diperhatikan yaitu pelaksanaan pengendalian persediaan bahan baku laundry [4-6]. Pengendalian persediaan bahan baku laundry masih dilakukan secara manual dengan melakukan pencatatan 
pada sebuah buku besar dan dalam estimasi produksi bahan baku selama ini sangat tidak optimal, karena dapat membebani keuangan pada Samarinda Laundry Mart dalam segi pengeluaran biaya produksi maupun biaya penyimpanan.

\section{Metode EPQ (Economic Production} Quantity) merupakan metode yang dapat membantu proses pengendalian persediaan bahan baku laundry. EPQ adalah metode pengendalian persediaan untuk menentukan besarnya volume produksi yang optimal dengan waktu yang optimal dan total biaya persediaan produksi serendah-rendahnya. Dalam metode ini jumlah produksi harus lebih besar pada jumlah permintaan. Dengan kata lain proses produksi dilakukan sebelum persediaan habis, jumlah persediaan akan berkurang dan bertambah secara bertahap untuk memenuhi permintaan. Sehingga Samarinda Laundry Mart dapat mengurangi beban biaya yang dikeluarkan dalam melakukan proses produksi bahan baku laundry [7 - 10].

Berdasarkan latar belakang diatas, penggunaan metode EPQ dapat membantu manajemen untuk pengoptimalan produksi bahan baku laundry dan miminimalkan total biaya yang diperlukan, sehingga persediaan bahan baku laundry pada Samarinda Laundry Mart tidak mengalami kekurangan atau kelebihan yang dapat mengganggu kegiatan pelayanan laundry. Metode EPQ akan diterapkan pada aplikasi berbasis android agar semua data yang masuk dan keluar pada Samarinda Laundry Mart dapat lebih mudah diproses serta produksi bahan baku berjalan secara optimal.

\section{METODOLOGI PENELITIAN}

Metodologi penelitian ini berisikan teori yang berkaitan dengan model pengembangan system waterfall dan tahap-tahap formula pengendalian bahan baku laundry menggunakan Metode EPQ.

\subsection{Model Waterfall}

Model Air Terjun (Waterfall) adalah model klasik yang bersifat sistematis, berurutan dalam membangun software [9-11]. Penelitian ini dilaksanakan melalui beberapa tahapan pengembangan waterfall sebagai berikut:

1. Analisis kebutuhan (Requirement Definition) meliputi penemuan atau mengembangkan dan menganalisis tindakan yang mungkin untuk dilakukan.

2. Desain sistem dan perangkat lunak (System and Software Design) bertujuan untuk memberikan gambaran umum kepada pemakai tentang sistem teknologi informasi yang baru.

3. Implementasi dan pengujian Unit (Implementasi and Unit Testing) mengenai proses pembuatan aplikasi dan penerapan metode yang digunakan.

4. Integrasi dan pengujian sistem (Integration and System Testing) merupakan tahap peralihan dari sistem yang lama ke sistem yang baru, untuk menuju ke sistem yang baru maka harus dilakukan beberapa pengujian metode pengujian yang digunakan adalah black box dan White Box.

5. Penggunaan dan pemeliharaan (Operation and Maintenance) merupakan proses 
penggunaan aplikasi yang telah selesai dibangun, selain itu juga tahap perawatan terhadap sistem yang telah berhasil di selesaikan pembangunannya.

Setiap tahapan dilakukan secara berurutan mulai dari langkah pertama sampai langkah terakhir, setiap langkah yang telah selesai dikerjakan harus dilakukan pengkajian ulang, tertera dalam alur penelitian pada Gambar. 1.

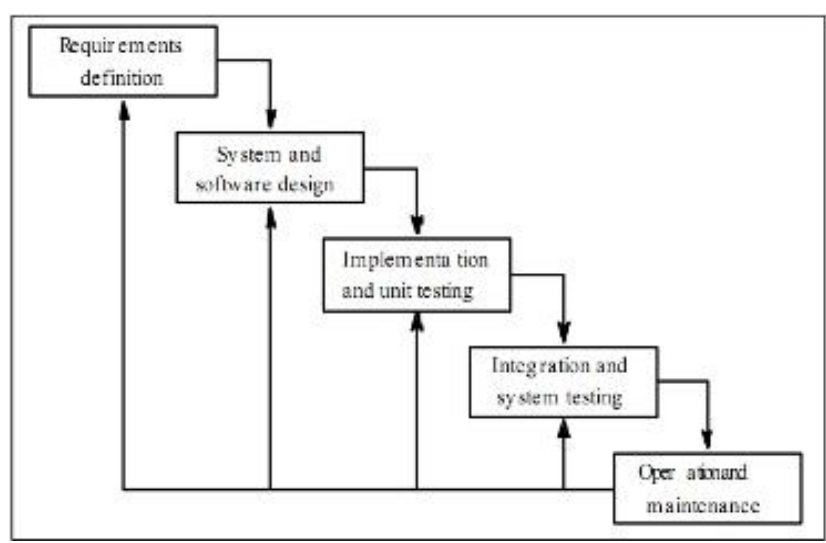

Gambar. 1 Alur Penelitian

\subsection{Metode EPQ (Economic Production Quantity)}

EPQ (Economic Production Quantity)

adalah pengembangan model persediaan dimana pengadaan bahan baku berupa komponen tertentu diproduksi secara massal dan dipakai sendiri sebagai sub-komponen suatu produk jadi oleh perusahaan.

EPQ (Economic Production Quantity) atau tingkat produksi optimal adalah sejumlah produksi tertentu yang dihasilkan dengan meminimumkan total biaya persediaan yang terdiri atas biaya set-up produksi dan biaya penimpanan. Model EPQ mengasumsikan bahwa penambahan persediaan secara bertahap dan terus menerus dalam periode produksi. Dengan demikian tingkat persediaan tidak akan pernah menjadi besar sejak produksi dan konsumsi secara bersama terjadi selama periode produksi $[7,10]$.

Unit yang akan diproduksi diambil dari gudang atau diterima dari supplier. Jika item dibeli dari supplier, penentuan harga adalah tanggungjawab department pembelian. Jika item diproduksi dalam pabrik, maka biaya produksi per unit terdiri dari tenaga kerja langsung, bahan baku langsung, dan biaya pabrik. Biaya pabrik adalah tenaga kerja tak langsung, bahan baku tidak langsung, penyusutan, pajak, asuransi, pemeliharaan, supervise, dan lain-lain. Keputusan utama yang harus diambil adalah menentukan jumlah produksi atau pesanan. Jumlah produksi yang meminimumkan total biaya persediaan adalah EPQ [7, 10]. Model EPQ menggunakan asumsi-asumsi sebagai berikut:

1. Produksi berjalan secara kontinu dengan laju produksi P per satuan waktu

2. Selama produksi dilakukan $\left(t_{p}\right)$, tingkat pemenuhan persediaan adalah sama dengan tingkat produksi dikurangi tingkat permintaan (P-D).

3. Ketika produksi berhenti pada satu waktu, maka persediaan akan berkurang dengan kecepatan D per satuan waktu

4. Tingkat persediaan adalah sama untuk tiap putaran produksi

5. Waktu tenggang (lead time) adalah konstan

6. Permintaan deterministik dengan laju permintaan diketahui

7. Tidak terjadi stock-out

Model matematis persamaan EPQ dapat dikembangkan melalui Gambar 2. berikut: 


$$
(P-D) t_{p}
$$

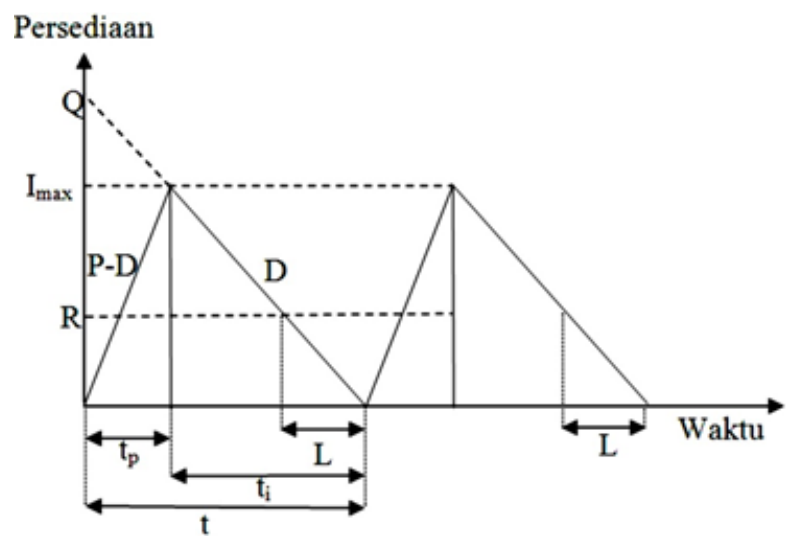

Gambar. 2 Grafik Economic Production

Quantity

Keterangan Gambar 2 :

$Q:$ Jumlah produksi dalam satu putaran produksi

$D$ : Rata-rata penyaluran per satuan waktu

$P$ : Rata-rata produksi per satuan waktu

$L$ : Waktu yang diperlukan untuk memproduksi kembali

$I_{\max }$ : Tingkat persediaan maksimal

$R$ : Persediaan hampir habis

$t_{p}:$ Waktu dimana dilakukan produksi

$t_{i}$ : Waktu dimana proses produksi berhenti

$t:$ Waktu satu putaran produksi

Dari Gambar 2. terlihat bahwa jumlah produksi tiap putaran harus memenuhi permintaan selama t, atau dinotasikan $Q=$ D.t. Sepanjang produksi terjadi, tingkat persediaan akan terus meningkat dengan kecepatan P-D, tetapi pada saat $t_{p}$ sampai dengan berikutnya, maka proses produksi sudah berhenti sedangkan permintaan dengan laju tetap sebesar D menjadikan grafik berubah menurun sampai posisi level persediaan mencapai titik nol kembali. Tingkat persediaan akan ada di suatu titik maksimum di mana produksi berhenti.

Tingkat persediaan maksimum menggunakan persamaan (1) :
Persediaan rata-rata akan sama dengan persamaan (2) :

$$
t_{p}\left(\frac{P-D}{2}\right)
$$

Untuk memenuhi persediaan sebesar Q diperlukan waktu selama tp dengan tingkat pertambahan persediaan sebesar $\mathrm{P}$ maka akan digunakan persamaan (3) :

$$
Q=t_{p} \cdot P \text { atau } t_{p}=\frac{Q}{P}
$$

Jika persediaan telah mencapai tingkat B, maka haus diadakan set-up (persiapan) produksi yang lamanya tergantung lead time (L). Jadi, L dalam model ini menyatakan waktu tunggu yang diperlukan untuk set-up (persiapan) produksi. maka persediaan rata-rata akan menjadi persamaan (4) :

$$
\frac{Q}{P}\left(\frac{P-D}{2}\right)=\frac{Q(P-D)}{2 P}=\frac{Q}{2}-\frac{Q D}{2 P}=\frac{Q}{2}\left(1-\frac{D}{P}\right)
$$

Sehingga diperoleh, Carrying cost rata-rata $=$

$$
\frac{Q}{2}\left(1-\frac{D}{P}\right) \cdot C_{c}
$$

Karena jumlah putaran produksi $=\frac{D}{Q}$

maka, Set-up cost rata-rata $=\frac{D}{Q} \cdot C_{s}$

Total Inventory Cost (TIC) adalah :

$$
T I C=\frac{Q}{2}\left(1-\frac{D}{p}\right) \cdot C_{c}+\frac{D}{Q} \cdot C_{s}
$$

Dengan mendiferensialkan persamaan TIC terhadap Q, maka; 


$$
\begin{aligned}
& \frac{d T I C}{d Q}=\frac{1}{2} \cdot\left(1-\frac{D}{P}\right) \cdot C_{c}-\frac{D}{Q^{2}} \cdot C_{s}=0 \\
&\left(1-\frac{D}{P}\right) \cdot C_{c} \cdot Q^{2}=2 \cdot D \cdot C_{s} \\
& Q^{2}=\frac{2 \cdot D \cdot C_{s}}{\left(1-\frac{D}{P}\right) \cdot C_{c}}
\end{aligned}
$$

Sehingga, diperoleh tingkat produksi optimal dalam satu putaran produksi yaitu (10):

$$
Q_{0}=\sqrt{\frac{2 \cdot D \cdot C_{s}}{\left(1-\frac{D}{P}\right) \cdot c_{c}}}
$$

Interval waktu optimal pada setiap putaran produksi yaitu:

$$
t_{0}=\frac{Q_{0}}{D}
$$

Tingkat persediaan maksimum di mana tahap produksi berhenti (12) :

$$
\mathrm{I}_{\max }=(\mathrm{P}-\mathrm{D}) \mathrm{t}_{\mathrm{p}}
$$

Menentukan Re-Order Points (ROP) (13) :

$$
R O P=d x\left(\frac{Q}{p}\right)
$$

Menentukan total biaya minimum (14) :

$T I C_{0}=\frac{Q_{0}}{2}\left(1-\frac{d}{p}\right) C_{c}+\frac{D}{Q_{0}} C_{s}$

\section{HASIL DAN PEMBAHASAN}

\subsection{Analisis Metode EPQ}

\begin{tabular}{|c|c|c|}
\hline \multirow[t]{3}{*}{ Tanggal } & $\begin{array}{l}\text { Jumlah } \\
\text { Permintaan/Kg }\end{array}$ & $\begin{array}{l}\text { Jumlah } \\
\text { Permintaan/Liter }\end{array}$ \\
\hline & Layanan & Bahan Baku \\
\hline & Laundry & \\
\hline $01 / 10 / 2018$ & 196,8 & 20,0 \\
\hline $02 / 10 / 2018$ & 208,1 & 15,0 \\
\hline $03 / 10 / 2018$ & 181,4 & 18,0 \\
\hline $04 / 10 / 2018$ & 200,8 & 25,0 \\
\hline $05 / 10 / 2018$ & 248,9 & 10,0 \\
\hline 06/10/2018 & 315,5 & 12,0 \\
\hline $07 / 10 / 2018$ & 230,3 & 25,0 \\
\hline 08/10/2018 & 223,2 & 20,0 \\
\hline 09/10/2018 & 28,9 & 10,0 \\
\hline $10 / 10 / 2018$ & 165,7 & 13,0 \\
\hline $11 / 10 / 2018$ & 176,0 & 23,0 \\
\hline $12 / 10 / 2018$ & 296,6 & 21,0 \\
\hline $13 / 10 / 2018$ & 295,7 & 18,0 \\
\hline $14 / 10 / 2018$ & 293,4 & 20,0 \\
\hline $15 / 10 / 2018$ & 208,7 & 25,0 \\
\hline $16 / 10 / 2018$ & 112,0 & 16,0 \\
\hline $17 / 10 / 2018$ & 193,2 & 25,0 \\
\hline $18 / 10 / 2018$ & 169,0 & 20,0 \\
\hline $19 / 10 / 2018$ & 328,0 & 13,0 \\
\hline $20 / 10 / 2018$ & 287,0 & 20,0 \\
\hline $21 / 10 / 2018$ & 253,8 & 15,0 \\
\hline $22 / 10 / 2018$ & 221,7 & 18,0 \\
\hline $23 / 10 / 2018$ & 198,2 & 25,0 \\
\hline $24 / 10 / 2018$ & 247,2 & 12,0 \\
\hline $25 / 10 / 2018$ & 175,1 & 18,0 \\
\hline $26 / 10 / 2018$ & 287,4 & 28,0 \\
\hline $27 / 10 / 2018$ & 340,2 & 23,0 \\
\hline $28 / 10 / 2018$ & 210,8 & 25,0 \\
\hline 29/10/2018 & 258,8 & 18,0 \\
\hline $30 / 10 / 2018$ & 125,1 & 15,0 \\
\hline $31 / 10 / 2018$ & 237,9 & 20,0 \\
\hline TOTAL & $7115,4 \mathrm{Kg}$ & \\
\hline TOTAL /ML & $142308 \mathrm{ml}$ & \\
\hline TOTAL/Liter & 142,308 liter & $\mathbf{5 8 6 , 0}$ liter \\
\hline
\end{tabular}

Untuk mengetahui bagaimana menganalisis menggunakan metode EPQ pada bahan cuci laundry untuk memperoleh hasil perhitungan yang tepat, dapat dilihat pada tabel 1 yang akan digunakan sebagai data kasus.
Tabel 1. Total Permintaan Bulan Oktober 2018

Jika setiap layanan membutuhkan bahan baku $20 \mathrm{ml}$ yaitu: detergen $5 \mathrm{ml}$, pewangi $5 \mathrm{ml}$, pelembut $5 \mathrm{ml}$, dan pelicin $5 \mathrm{ml}$. Maka bahan baku yang habis terpakai adalah 7115,4 $\mathrm{kg}$ x 20 $\mathrm{ml}=142308 \mathrm{ml}=142,308$ liter. Dari tabel 4.1 didapatkan total permintaan pada bulan oktober adalah 142,308 liter untuk layanan laundry dan 586 liter untuk bahan baku yang dijual. Jadi, total permintaan keseluruhan dalam bulan oktober 2018 adalah 728,308 liter. 
Jika pemilik ingin melakukan pembelian bahan baku untuk bulan depan dengan melihat berapa jumlah bahan baku yang dihabiskan dibulan sebelumnya maka digunakan rumus EPQ untuk mengukur seberapa banyak pembelian bahan baku. dilakukan dengan frekuensi pembelian yang tepat untuk pengendalian bahan bakunya.

Diketahui:

Biaya Produksi (S)

Biaya Penyimpanan $(\mathrm{H})$

Hari Kerja/bulan

Produksi/hari (p)

Permintaan/hari (d) $=\operatorname{Rp} 22000,-$ $=\operatorname{Rp} 2900,-$ $=31$ hari $=30$ liter $=728,308$

liter/31 = 23,494 liter

Hasil Perhitungan EPQ:

Step 1: Tingkat Produksi Optimal

$$
Q_{0}=\sqrt{\frac{2.728,308.22000}{2900\left(1-\frac{23,494}{30}\right)}}=226 \text { liter }
$$

Step 2: Frekuensi Produksi Optimal

$$
\text { putaran produksi }=\frac{728,308}{226}=3 \mathrm{kali}
$$

Step 3: Siklus Produksi Optimal

$$
t_{0}=\frac{226}{23,494}=9,6 \text { hari }=10 \text { hari }
$$

Step 4: Maksimal Persediaan

$$
I_{\text {max }}=\left(1-\frac{23,494}{30}\right) \times 226=49 \text { liter }
$$

Step 5: Minimal Persediaan

$$
R O P=23,494 \times\left(\frac{226}{30}\right)=176,987 \text { liter }
$$

Step 6: Total Biaya Minimum Persediaan

$$
\begin{aligned}
\text { IIC }_{0}=\frac{226}{2}(1 & \left.-\frac{23,494}{30}\right) 2900 \\
& +\frac{728,308}{226} 22000 \\
& =R p 141.967,-
\end{aligned}
$$

Jadi, Metode EPQ ini berfungsi tidak hanya untuk menghitung total minimum biaya persediaan saja, namun juga dapat menghitung tingkat produksi, frekuensi produksi, siklus produksi yang optimal, maksimal persediaan, dan minimal persediaan.

\subsection{Implementasi}

Halaman utama jika toko binatu belum dibuat akan tampil gambar seperti pada gambar 3. Tekan tambah lalu masukkan data binatu dengan benar. Jika laundry sudah dibuat, untuk mengubah datanya pilih tombol ubah kemudian masuk ke halaman ubah binatu. Selain itu foto laundry juga dapat diubah jika sudah tekan tombol simpan.:

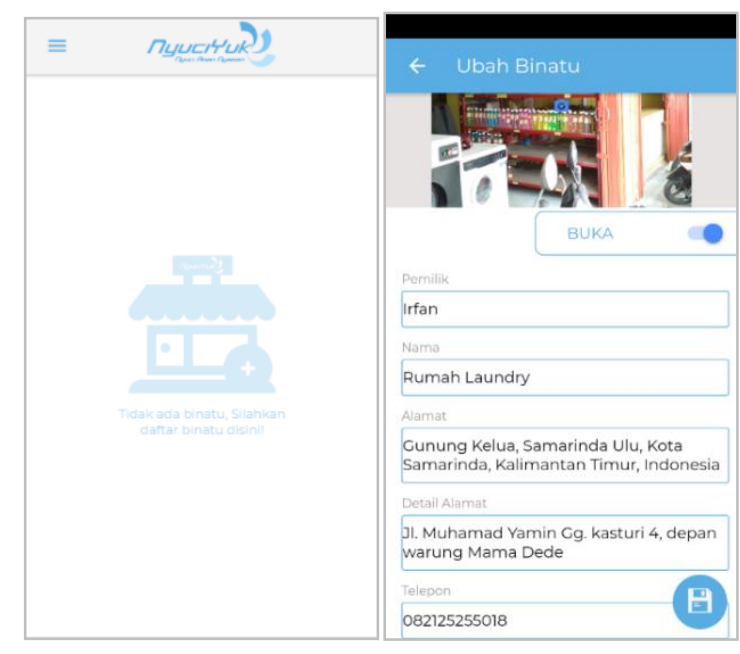

\section{Gambar. 3 Tampilan Menu Utama}

Halaman login digunakan untuk masuk kedalam aplikasi dengan mamasukkan email dan password yang telah terdaftar. Jika belum terdaftar bisa menekan tulisan "Daftar Sekarang" seperti gambar 4. Terdapat dua hak akses yang pertama sebagai pemilik dan yang kedua sebagai pekerja. Untuk hak akses pemilik semua fitur dapat diakses sedangkan jika login sebagai 
pekerja hanya bisa mengakses halaman transaksi, halaman transaksi aktif, halaman riwayat transaksi.

Pada gambar 4. halaman register ini digunakan untuk mendaftarkan akun pemilik baru. Masukkan nama, alamat, telepon, email, password, dan retype password dengan benar lalu tekan tombol daftar. Jika ada penulisan yang salah aplikasi tidak dapat melakukan pendaftaran, maka isi sesuai dengan ketentuan. Jika sudah benar akan masuk ke halaman utama.

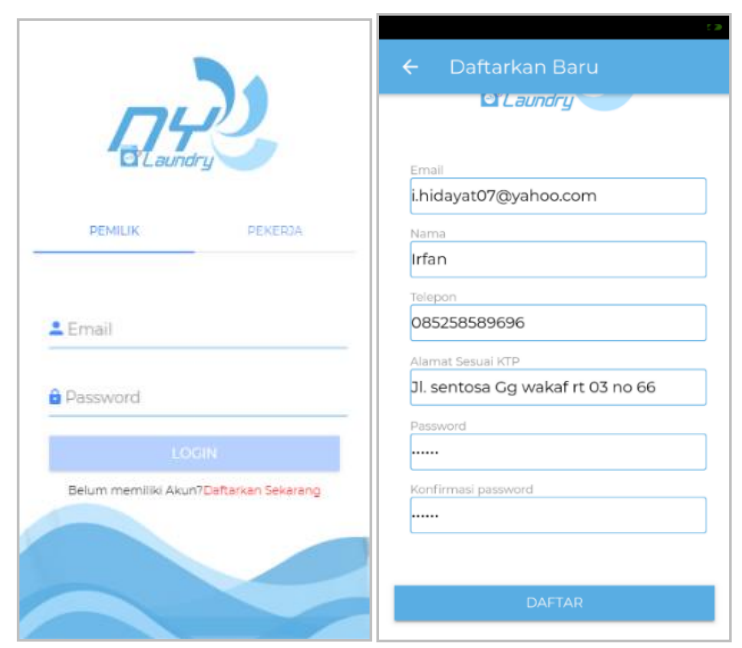

Gambar. 4 Halaman Login dan Register

Halaman transaksi digunakan untuk memilih layanan dan bahan baku apa saja yang akan dijual, terdapat dua pilihan yaitu transaksi laundry dan transaksi bahan baku laundry seperti yang terihat pada gambar 5. Untuk melihat daftar layanan tekan tombol "layanan" jika melihat daftar bahan baku tekan tombol "bahan baku". Setelah semua terpilih tekan tombol "bayar" untuk masuk ke halaman pembayaran. Untuk tombol bersimbol daftar berfungsi sebagai penampung layanan atau bahan baku apa saja yang dipilih dan juga terdapat pencarian layanan. untuk tombol bersimbol kalkulator digunakan untuk menampilkan kalkulator. Selain itu simbol lonceng digunakan untuk menampilkan pemberitahuan jika ada bahan baku yang hamper habis.

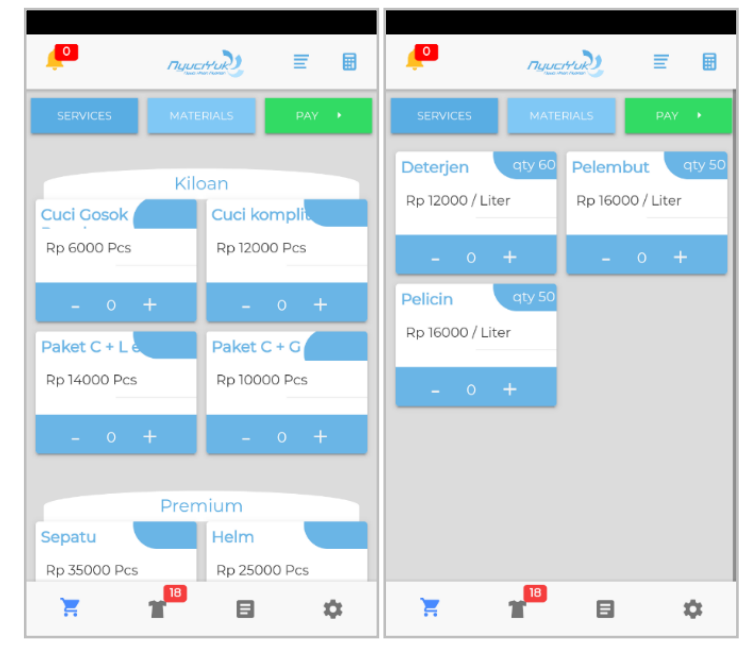

Gambar. 5 Halaman Transaksi

Halaman pembayaran masukkan nama, alamat, telepon, jadwal penyelesaian dan catatan jika diperlukan. Setelah itu masukkan jumlah pembayaran dan tekan tombol nota untuk masuk ke halaman nota. Halaman nota binatu menampilkan nota yang akan dicetak. Selain dicetak, nota juga dapat diolah menjadi bentuk pdf dan bisa dikirim lewat email.

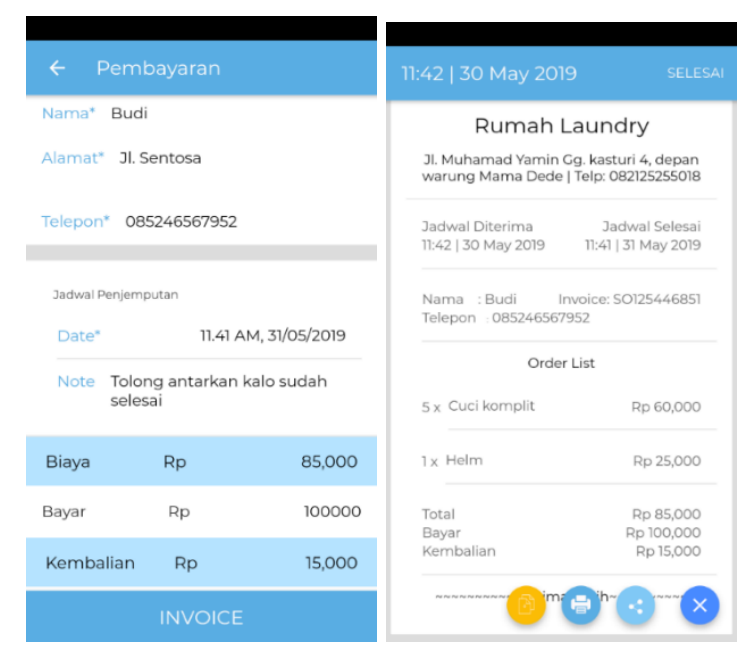

Gambar. 6 Halaman Pembayaran dan Nota 
Halaman manajemen binatu digunakan untuk melakukan tambah, ubah, dan hapus atau mengelola data-data laundry terdapat 4 tombol pilihan yaitu tombol data layanan, tombol data bahan baku, tombol data pekerja, dan tombol data biaya.

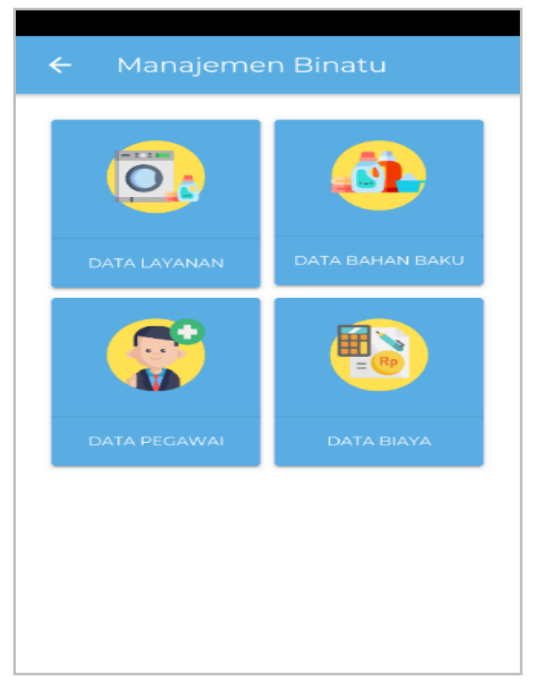

Gambar. 7 Halaman Manajemen Binatu

Halaman perhitungan EPQ digunakan saat pemilik ingin menentukan tingkat produksi optimal, persediaan maksimal, frekuensi produksi, perkiraan bahan baku habis, batas minimum persediaan. selain itu juga menghitung total biaya penyimpanan, total biaya produksi dan TIC (Total Inventory Cost).

Untuk memperoleh hasil pengendalian persediaan menggunakan metode EPQ setiap bulannya, pertama masukkan jumlah total permintaan yang didapat dari total bahan baku yang digunakan setiap transaksinya ditampilkan dihalaman beranda. Biaya penyimpanan didapat dari biaya penyimpanan per liter bahan bakunya ditampilkan pada halaman daftar bahan baku. Biaya produksi didapat dari data biaya perbulan yang ditampilkan dihalaman daftar biaya. Lalu masukkan jumlah hari kerjanya dan terakhir jumlah produksi perharinya. Maka akan dilakukan perhitungan EPQ dan didapatkan hasilnya seperti pada gambar 8. Jika ingin menyimpan laporannya dalam bentuk PDF tekan tombol pada pojok kanan atas.

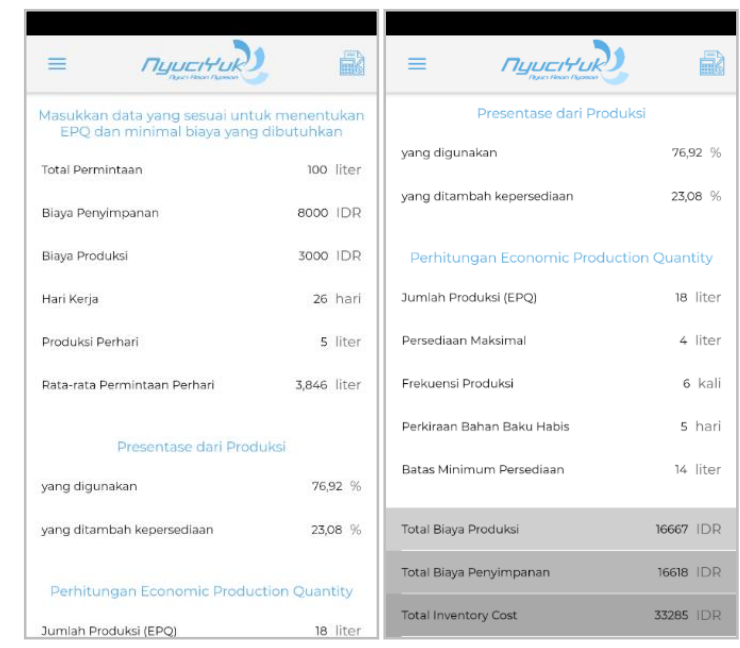

Gambar. 8 Halaman Perhitungan Metode EPQ

Halaman beranda terdapat seluruh rekap total pendapatan, total biaya, dan keuntungan setiap bulannya digambarkan dalam bentuk grafik pie. Selain itu juga terdapat total permintaan bahan baku, dan permintaan bahan baku detailnya setiap bulan.

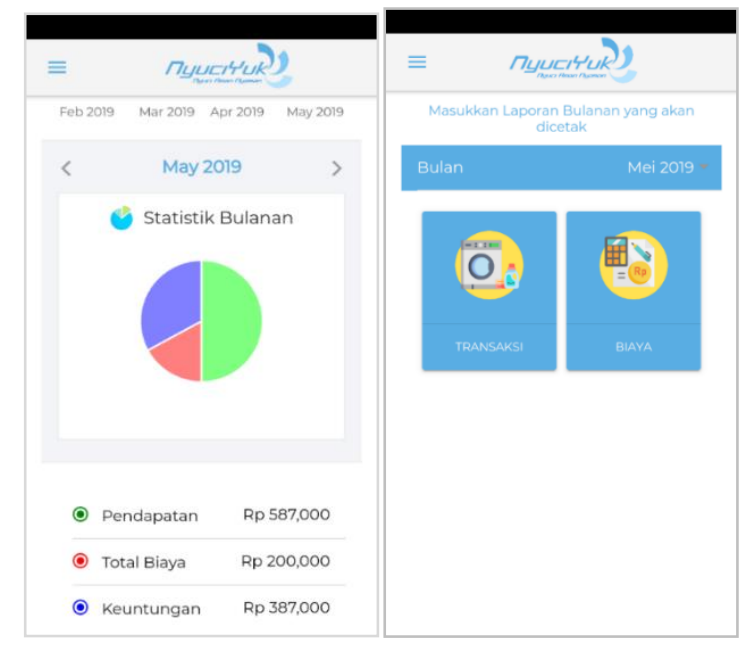

Gambar. 9 Halaman Beranda dan Laporan 


\section{KESIMPULAN}

Dengan adanya hasil penelitian yang dilakukan dan berdasarkan uraian-uraian yang dibahas dalam bab-bab sebelumnya, maka dapat ditarik kesimpulan bahwa:

1. Penerapan metode EPQ (Economic Production Quantity) pada pengendalian bahan baku di Samarinda Laundry Mart berbasis android dengan menggunakan metode pengembangan aplikasi yaitu Model Air Terjun (Waterfall).

2. Dengan menerapkan metode EPQ (Economic Production Quantity) manajemen bahan baku pada Samarinda Laundry Mart menjadi mudah dikelola karena dapat ditentukan jumlah dan frekuensi produksi bahan baku yang optimal sehingga meminimumkan total biaya perbulan

3. Aplikasi ini menggunakan dua user yaitu user pemilik pada aplikasi ini mencakup level admin untuk mengelola dan manajemen data laundry dan user pekerja hanya untuk melakukan transaksi.

\section{UCAPAN TERIMA KASIH}

Judul Dibiayai oleh Direktorat Riset dan Pengabdian Masyarakat Direktorat Jenderal Penguatan Riset dan Pengembangan Kementerian Riset, Teknologi, dan Pendidikan Tinggi sesuai Dengan Kontrak Penelitian Tahun Anggaran 2020.

\section{DAFTAR PUSTAKA}

[1] Bagyono. Management Housekeeping Hotel. Bandung: Alfabeta. 2012.

[2] Ikhsan, Fauzar. "Kinerja Section Laundry
Terhadap Tingkat Kepuasan Tamu Di Best Western Hotel Asean Internasional Medan”. 2012.

[3] Aswi, Bang. Bisnis laundry kiloan. Niaga Swadaya, 2013.

[4] Baroto, T. Perencanaan dan pengendalian produksi. Jakarta: Ghalia Indonesia. 2012.

[5] Nurhasanah, Nunung. "Perencanaan Pengendalian Produksi dan Persediaan Industri Pasta PT "xyz"." Industrial and Systems Engineering Assessment Journal (INASEA)-Discontinued 6.2. 2012.

[6] Nasution, Arman Hakim, and Yudha Prasetyawan. "Perencanaan dan pengendalian produksi." Yogyakarta: Graha Ilmu. 2008.

[7] Yamit, Z. Manajemen Persediaan (Cetakan Pertama). Yogyakarta: Ekonisia Fakultas Ekonomi UII. 2012.

[8] Yamit, Z. Manajemen Produksi dan Operasi. Edisi Kedua. Yogyakarta: Ekonisia. 2012.

[9] Sayuni, N. P. F., Zukhri, A., \& Meitriana, M. A. Analisis Jumlah Produksi Optimal Dengan Metode Economic Production Quantity (EPQ) Pada UD. Sinar Abadi Singaraja. Jurnal Pendidikan Ekonomi Undiksha, 4(1). 2014.

[10] Meitriana, S. P. M. A., Zukhri, A., \& Sayuni, N. P. F. Analisis Jumlah Produksi Optimal dengan Metode Economic Production Quantity (Epq) pada Ud. Sinar Abadi Singaraja. Jurnal Jurusan Pendidikan Ekonomi Undiksha, 4(1), 5272. 2014.

[11] Madilah, A. J. E., Sutrisno, A. dan Mende, J. Penentuan Persediaan Bahan Baku Kopra Pada PT. Salim Ivomas Pratama Tbk Dengan Pendekatan EPQ (Economic Production Quantity). Jurnal. Jurusan Teknik Mesin. Manado: Universitas Sam Ratulangi. 2013. 